\title{
Genotypes of Hepatitis C Virus in Kuwait
}

\author{
A.S. Pacsa ${ }^{a}$ S. Al-Mufti ${ }^{b}$ T.D. Chugh ${ }^{a}$ G. Said-Adia \\ aDepartment of Microbiology, Faculty of Medicine, Health Sciences Center, Kuwait University and \\ bVirology Laboratory, Ministry of Health, Kuwait
}

\section{Key Words}

Genotype $\cdot$ Hepatitis C virus $\cdot$ Kuwait

\begin{abstract}
Hepatitis C virus (HCV) genotypes in 144 patients in Kuwait were determined by the Murex Anti-HCV Serotyping Assay. Twenty-nine (38\%) of 77 Kuwaiti patients were found to be infected with genotype 4 and $27 \%$ with genotype 1 while of the 41 Egyptian expatriate patients $37(90 \%)$ were infected with genotype 4 . Results show that although in native Kuwaiti patients the dominant genotype is 4 , other genotypes, especially type 1 , occur frequently.
\end{abstract}

Copyright $\odot 2001$ S. Karger AG, Basel

The geographical distribution of hepatitis $\mathrm{C}$ virus (HCV) genotypes is important for future vaccine development as well as determining the source of infection [1]. Furthermore, the severity of infection and the effectiveness of interferon therapy may be influenced by genotypes.

Only limited data are available for the Middle East regarding genotype distribution of $\mathrm{HCV}$ [2]. Studies thus far have shown that genotype 4 is dominant in Egypt; more than $90 \%$ of HCV strains belong to this type. In oth- er Middle Eastern countries, the pattern is somewhat different: in Syria type 4 and type 1 are predominant, while in Lebanon and Iraq it seems that it is type 1 [3]. In Saudi Arabia, where a relatively large number of samples have been analyzed, it was found that type 4 was represented in $48 \%$ of the population. The other rather frequent genotype was type 1 [4]. The most predominant genotypes worldwide are 1, 2 and 3 [3]. Other genotypes are confined to certain areas, such as type 5 for Hong Kong and South Africa. In this study, we report the genotypic distribution among 144 serum samples from HCV antibodypositive patients in Kuwait.

In addition to molecular methods, genotypes of $\mathrm{HCV}$ can be determined by serological techniques based on the detection of genotype-specific antibodies to synthetic peptide antigens representing the core and nonstructural (NS) regions of the viral protein [5]. HCV can be classified into 6 major genotypes and several subtypes [6]. ELISA-based assays have also been developed to determine the antibodies to those specific peptide antigens representing the major genotypes. The antigens used in the assay are genotype-specific, showing no cross-reactivity among the 6 major genotypes. Although this serogenotyping is limited to identifying the 6 major genotypes, it gives valuable data on the worldwide distribution of HCV genotypes.

Here in Kuwait we have analyzed $144 \mathrm{HCV}$ antibodypositive samples which were selected from those sent for

\begin{tabular}{ll}
\hline KARGER & ( ) 2001 S. Karger AG, Basel \\
Fax +4161306 1234 & 1011-7571/01/0101-0055\$17.50/0 \\
$\begin{array}{l}\text { E-Mail karger@karger.ch } \\
\text { www.karger.com }\end{array}$ & $\begin{array}{l}\text { Accessible online at: } \\
\text { www.karger.com/journals/mpp }\end{array}$
\end{tabular}

Dr. A.S. Pacsa

Department of Microbiology, Faculty of Medicine

Health Sciences Center, Kuwait University

PO Box 24923, 13110 Safat (Kuwait)

Fax+965 533 2719, E-Mail pacsa@hsc.kuniv.edu.kw 
Table 1. Distribution of major HCV genotypes according to nationality in Kuwait

\begin{tabular}{lclllllll}
\hline Nationality & \multirow{2}{*}{ Number } & \multicolumn{9}{l}{ Genotype } & UT & Mx \\
\cline { 3 - 7 } & & 1 & 2 & 3 & 4 & & \\
\hline Kuwaiti & 77 & $21(27)$ & $1(1.3)$ & $7(9)$ & $29(38)$ & $15(19.5)$ & $4(5.2)$ \\
Egyptian & 41 & $2(5)$ & - & - & $37(90)$ & $2(5)$ & - \\
NK & 20 & $1(5)$ & - & $1(5)$ & $12(60)$ & $3(15)$ & $3(15)$ \\
Syrian & 3 & 3 & - & - & - & - & - \\
Indian & 1 & 1 & - & - & - & - & - \\
Pakistani & 2 & - & - & 2 & - & - & - \\
\hline Total & 144 & 28 & 1 & 10 & 78 & 20 & 7 \\
\hline
\end{tabular}

Figures in parentheses represent percentage. Kuwaiti nationality refers to the sector of the Kuwaiti population who are genuine Kuwaiti citizens, having lived in Kuwait for generations. Egyptian nationality refers to Egyptian expatriates who have been working in Kuwait for years. NK refers to non-Kuwaitis. This category includes individuals whose nationality cannot be determined, but are of Middle Eastern origin permanently residing in Kuwait. $\mathrm{UT}=$ Untypable genotypes; $\mathrm{Mx}=$ mixed genotypes. hepatitis serology by various hospitals in Kuwait to the Department of Microbiology, Faculty of Medicine, and the Public Health Virology Laboratory, Ministry of Health, Kuwait. Sera were screened first with the Abbott IMx HCV version 3 microparticle immunoassay. The assay is based on recombinant $\mathrm{HCV}$-specific antigens (HCr43 contains sequences of both core structural and nonstructural antigens while c200, c100-3 and NS5 represent antigens related to nonstructural regions of $\mathrm{HCV}$ ). Sera being HCV-antibody-positive by this assay were retested with (1) Organon LiaTek HCV III line immunoassay, which uses HCV E2/NS1, NS3, NS4, NS5 core proteins on the strip and (2) Genlabs Diagnostics HCV Blot 3.0 Western blot assay, which uses 4 nonstructural and 1 capsid-related antigens on the nitrocellulose strip. The serogenotypic determination of the LiaTek/Genlabspositive samples was done using Murex Anti-HCV Serotyping Assay version 1-6. This serotyping utilizes a larger number of synthesized HCV-specific, branched peptide antigens, representing the variable regions from NS4 of HCV genotypes 1, 2, 3, 4, 5 and 6. All tests were performed according to the protocol given by the manufacturers.

In Kuwait, $75 \%$ of the population of 2 million are expatriates, the majority from South East Asian and Middle Eastern countries. This factor may have an impact on the prevalence of $\mathrm{HCV}$ antibodies and the distribution of genotypes. The results are summarized in table 1. Regarding the genotyping distribution of $\mathrm{HCV}$, our data is in agreement with that found in Saudi Arabia [4] where the prevalence of genotype 4 in Saudi nationals was $48 \%$ fol- lowed by type 1 with $28 \%$ compared to Kuwaiti nationals of 38 and $27 \%$, respectively. Although genotype 4 seems to be most prevalent in both Saudi Arabia and Kuwait, type 1 is represented with a relatively large percentage. This is definitely in contrast to the pattern which characterizes the expatriate Egyptian population in Kuwait, who are almost exclusively infected with HCV genotype 4 . This unique, homogenous pattern was also found among Egyptian health care workers in a Kuwaiti hospital where of the $16 \mathrm{HCV}$ antibody-positive Egyptians, 13 were infected with HCV type 4 [7]. Although many of the Egyptians have been living in Kuwait for longer than 10 years, they are still infected with HCV genotype 4. This may indicate that this infection is acquired in early childhood. On the other hand, there is an example of an Italian who lived in Egypt for approximately 20 years and had an $\mathrm{HCV}$ infection of genotype 4 [3]. Genotypes of 20 samples $(14.8 \%)$ of the 144 tested could not be determined. This figure agrees well with the results of Saudi Arabian (16.8\%) and Kuwaiti (17\%) studies [4, 7]. Nevertheless, these samples require further study for determining whether new HCV genotypes are present in this part of the world.

\section{Acknowledgement}

This study was supported by the Department of Microbiology, Faculty of Medicine and the Office of the Vice Rector for Research, Kuwait University, Kuwait, grant No. MI-108 and MI-112. 


\section{References}

1 Pawlotsky JM, Tsakiris L, Roudot-Thoraval F, Pellet C, Stuyver L, Duval J, Dhumeaux D: Relationship between hepatitis C virus genotypes and sources of infection in patients with chronic hepatitis C. J Infect Dis 1995;171: 1607-1610.

2 Dusheiko G, Schmilovitz-Weiss H, Brown D, McOmish F, Yap PL, Sherlock S, McIntyre N, Simmonds P: Hepatitis $C$ virus genotypes: An investigation of type-specific differences in geographic origin and disease. Hepatology 1994;19:13-18.
3 McOmish F, Yap PL, Hart H, Peerlink K, Burns SM, Simmonds P: Geographical distribution of hepatitis $\mathrm{C}$ virus genotypes in blood donors: An international collaborative study. J Clin Microbiol 1994;32:884-892.

4 Shobokshi OA, Serebour FE, Skakni L, Al-Saffy YH, Ahdal MN: Hepatitis genotypes and subtypes in Saudi Arabia. J Med Virol 1977;58: 44-48.
5 Tanaka T, Tsukiyamakohara K, Yagi S, Hasegawa A, Ohta Y, Kohara M: Significance of specific antibody assay for genotyping of hepatitis C virus. Hepatology 1994;19:1347-1353.

6 Simmonds P, et al: A proposed system for the nomenclature of hepatitis $\mathrm{C}$ viral genotypes. Hepatology 1994;19:1321-1324.

7 Hasan F, Askar H, Al-Khalidi J, Al Shamali M, Al-Nakib B: Lack of transmission of hepatitis C virus following needlestick accidents. Hepatogastroenterology 1999;45:1678-1681. 